in the contracts the right of supervision by the appropriate international agency. Contract orders placed this year, which will not operate before 1961 or 1962, will enable the Government to insist upon whatever methods of inspection seem proper and desirable. Mr. Macmillan also pointed out that the Agency is a board of twenty-three governors from as many countries with somewhat different approaches to this matter and that it may be difficult to get such a board to agree to adopt a particular form of technical operation. If it cannot be done in one particular way there may be some other agency or method for securing effective control; we have perhaps three or four years in which to work out the best method.

\section{Nuclear Reactor for Winfrith Heath}

IN a written answer in the House of Commons on July 8, the Prime Minister said that it has been decided on technical grounds that the homogeneous aqueous reactor system planned for Winfrith Heath is not at present suitable for a major research and development effort, either by the Atomic Energy Authority alone or as a joint programme under the European Nuclear Energy Agency. Discussions are now in progress in the Agency about a joint research programme on the high-temperature gas-cooled reactor, a system which holds considerable promise for generating power but which has not yet been investigated in detail. This would include the construction of an experimental reactor in the United Kingdom, and Mr. Macmillan hoped that a satisfactory agreement will be concluded in the next few months. On the same day it was stated that the British Government contributes about one-quarter to the total budget for 1958 of $£ 4,660,000$ of the European Organization for Nuclear Research.

\section{Research in the Aircraft Industry}

The debate on the aircraft industry, which was opened by Viscount de L'Isle in the House of Lords on July 16, is of interest for the consistent emphasis laid on the importance of research by almost all speakers. Lord de L'Isle said that the industry is one of three or four in Britain in which it is vital to the national economy that it should gain and maintain a leading position in the world, and added that in this industry the demand to plough back money in research and development is the most insistent; he put the necessary figure at $20-30$ per cent of turnover. Lord Ogmore, who asked again for an independent inquiry into the structure and situation of the industry, questioned whether it was possible to provide finance for research and development necessary for supersonic airliners from non-military sources alone, and said that about six of the 200 firms in the industry are responsible for 80-90 per cent of the output. The Earl of Swinton, urging that it is the duty of the Government to have a definite policy of development and to make this plain to the industry, argued firmly that we cannot afford to skimp expenditure on research, while Lord Adrian, pointing out that the aircraft industry is in the forefront of technological progress, said that there is scarcely any field of technical advance which did not receive an immense stimulus from war-time developments in aircraft. Instancing radio, metallurgy, engine design, electronic control and almost every kind of fine engineering, he said that the problem is whether we could afford to lose the technology which would go into the planes no longer required for defence, since it would be applied to machines and have just as much influence on industrial development as many developments in nuclear energy. The value of the applied research required for building a full-scale machine was not easily over-rated, and Lord Adrian believed that an important case can be made for Government sponsorship of the design and construction of some advanced machines. Viscount Caldecote strongly supported Lord Adrian's plea, pointing out also the vital need for continuity in research and suggesting allocation of finance for research and development over a five-year period: research cannot be stopped and restarted. He also supported Lord Weeks in a plea for clear guidance to the industry from the Government in poliey. Lord Pakenham advocated the formation of a board in the Ministry of Supply, including industrial representation from outside the aircraft industry. Lord Mancroft, in reply, agreed as to the vital importance of research, but added little to the Minister of Supply's statement in the House of Commons on May 22 in reaffirming that the Government would continue to support the basic research necessary for the industry to survive, both in Government establishments and in industry, and that this would include the construction of research aircraft.

\section{The Clean Air Act, 1956}

As from June 1, 1958, the Clean Air Act, 1956, much of which has been in operation since the beginning of 1957, is fully in force, and it will be an offence punishable by fine to emit 'dark smoke' (defined as as dark or darker than shade 2 on the Ringelmann Chart) from any chimney in England and Wales. The ban on dark smoke applies to all buildings, and to railway engines and ships, but it will chiefly affect industrial and commercial premises, and the Minister of Housing and Local Government has issued a Memorandum on the Industrial Provisions (pp. 20. London: H.M. Stationery Office, 1958. $1 s$. net) to assist local authorities in administering these provisions of the Act. It directs attention to certain allowable defences and emphasizes the economies in fuel which can result from measures to reduce smoke. Surveys of Lancashire boilers carried out in 1956 by the National Industrial Fuel Efficiency Service indicate that adoption of measures to improve fuel efficiency on the 18,000 boilers in regular use should offer a saving of 3 million tons of coal a year against a capital expenditure of not more than $£ 14$ million. The Act also requires steps to be taken to reduce the emission of grit and dust from industrial chimneys. New furnaces installed after June 1 for burning pulverized fuel or more than 1 ton per hour of other solid fuel must be fitted with grit- and dustarresting plant approved by the local authority.

\section{European Agricultural Aviation Centre}

A European Agricultural Aviation Centre has been set up under the auspices of the European Productivity Agency of the Organization for European Economic Co-operation, with headquarters at The Hague. Its task is to promote co-operation and efficiency in agricultural aviation in Europe and to act as a co-ordinating centre for the dissemination of information and the stimulation of research and development in this field. The need for such a centre has long been apparent in agricultural, industrial and scientific circles. The special type of aircraft used in 